\title{
Core Sample Descriptions and Summary Logs of Six Wells Within the Hanford Reservation
}

\author{
W. K. Summers
}

Randall T. Hanson

January, 1977

Prepared for the U.S. Energy Research and Development Administration Under Contract EY-76-C-06-2130

Atlantic Richfield Hanford Company Richland, Washington 99352 


\section{Atlantic Richfield Hanford Company \\ Richland, Washington 99352}

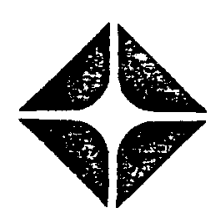

\section{NOTICE}

THIS REPORT WAS PREPARED AS AN ACCOUNT OF WORK SPONSORED BY THE UNITED STATES GOVERNMENT. NEITHER THE UNITED STATES NOR THE UNITED STATES ENERGY RESEARCH AND DEVELOPMENT ADMINISTRATION, NOR ANY OF THEIR EMPLOYEES, NOR ANY OF THEIR CONTRAITORS, SUBCONTRACTORS, OR THEIR EMPLOYEES, MAKES ANY WARRANTY, EXPRESS OR IMPLIED, OR ASSUMES ANY LEGAL LIABILITY DR RESPONSIBILITY FOR THE ACCURACY, COMPLETENESS, OR USEFULNESS OF ANY INFORMATION OR PROCESS DISCLOSED, OR REPRESENTS THAT ITS UISE WOULD NOT INFRINGE PRIVATELY OWNED RIGHTS. 
CORE SAMPLE DESCRIPTIONS AND SUMMARY LOGS OF SIX WELLS WITHIN THE HANFORD RESERVATION

W. K. Summers

R. T. Hanson

W. K. Summers and Associates

Consultants

January 1977

This report was prepared as an account of work This repon was prepared as an sceount Neither the Sponit States Department of Uned Ster any of their Energy, nor any of theirs, or their employees, makes contractors, subcentace implied, or assumes any legal any warsanty, express or in the or arcy completeness liability or responsibsilty for the accurasy, product or or usefulness of any in forents that its use would not process disclosed, or tepresents

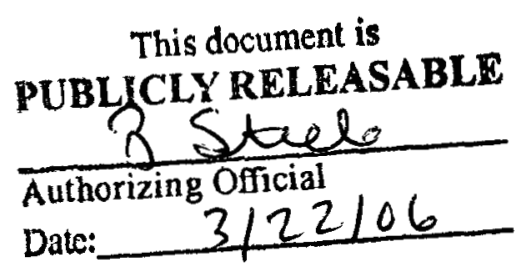

This report is based on work sponsored by Atlantic Richfield Hanford Company under United States Energy Research and Development Administration Contract EY-76-C-06-2130. 
ABSTRACT

This report presents the description and summary logs of core samples from six wells and test holes drilled within the Hanford Reservation. 
Introduction...........................

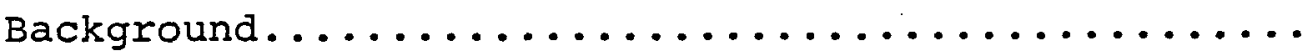

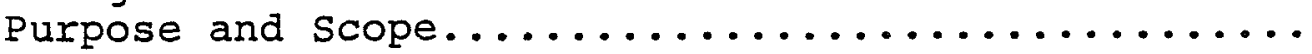

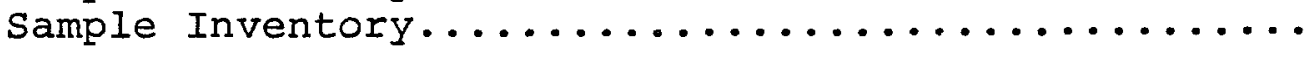

study Methods............................. 4

Descriptions............................ 4

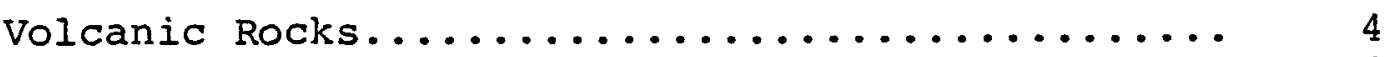

Sedimentary Rocks....................... 4

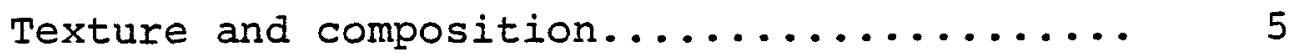

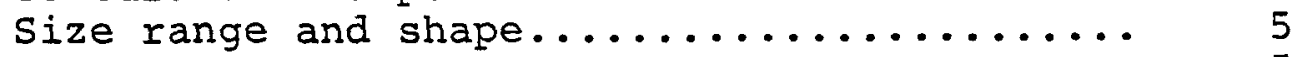

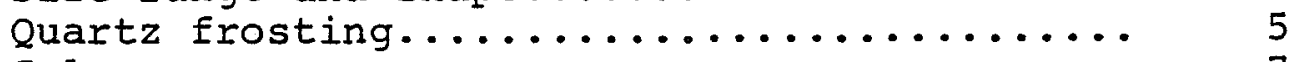

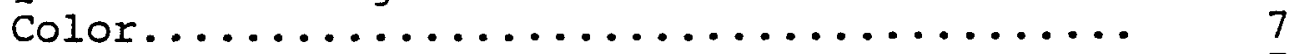

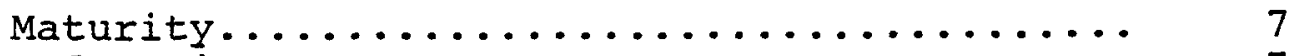

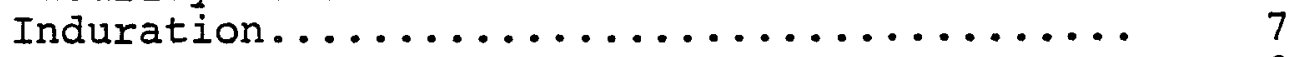

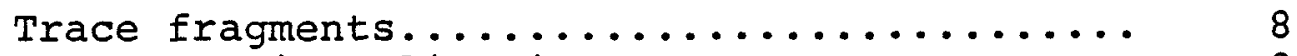

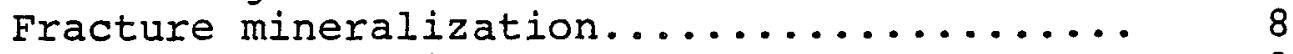

sedimentary fabric and structure........... 9

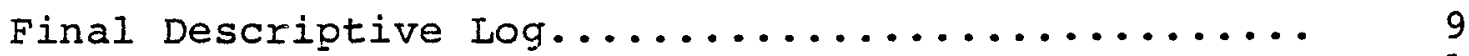

summary $\log \ldots \ldots \ldots \ldots \ldots \ldots \ldots \ldots \ldots \ldots \ldots \ldots . . \ldots \ldots \ldots$

References Cited.......................... 12

Summary $\operatorname{Logs} \ldots \ldots \ldots \ldots \ldots \ldots \ldots \ldots \ldots \ldots \ldots \ldots \ldots \ldots$ 


\section{LIST OF ILLUSTRATIONS}

Tables

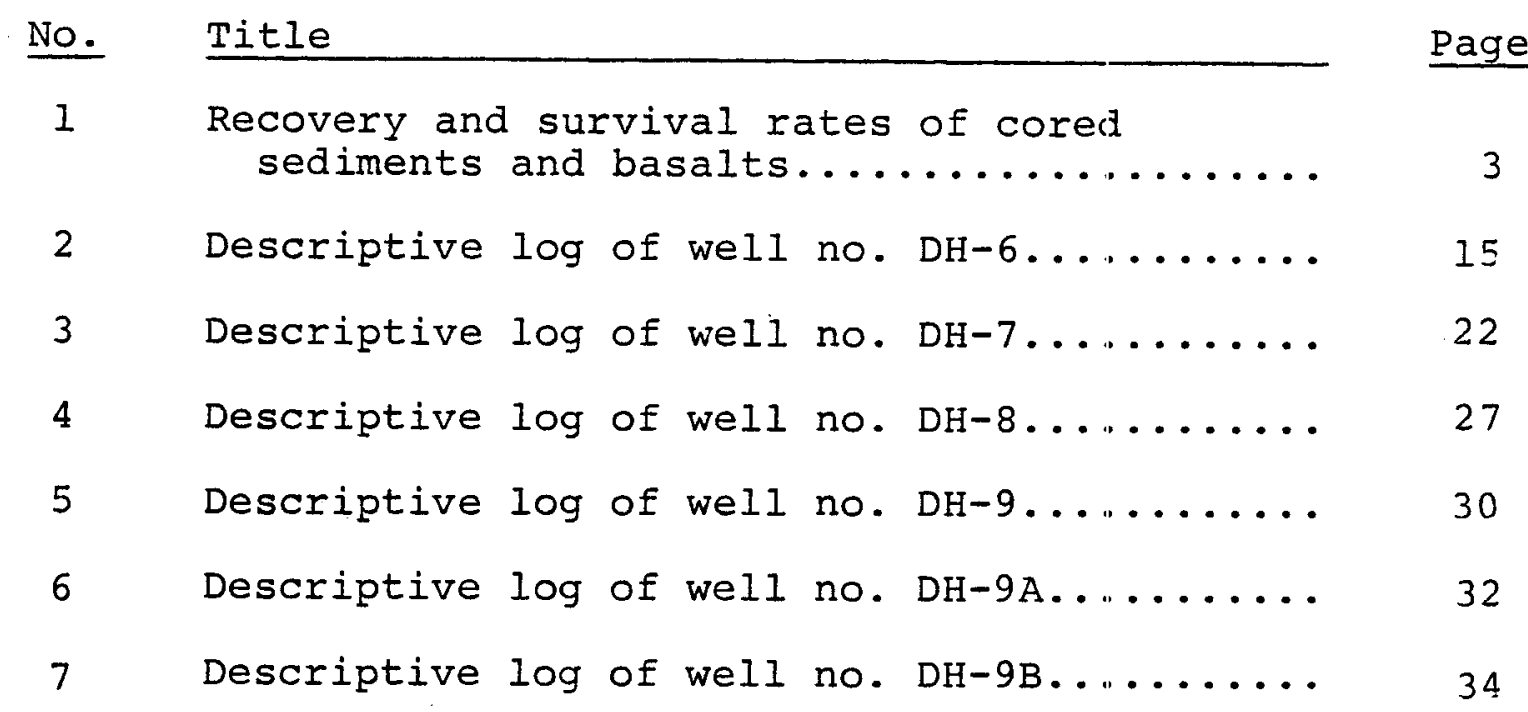

Figures

No. Title

$\underline{\text { Page }}$

1 Classification of clastic sedimentary rocks. 6

2 symbols used on summary logs.............. 11

Plate

No. Title

$\underline{\text { Page }}$

1 Location of wells for which sample suites are described...................... in pocket 


\section{INTRODUCTION}

\section{Background}

From February through May, 1976, Atlantic Richfield Hanford Company core drilled selected sites on the Hanford Reservation. Five wells originally drilled with cable tools, DH-6, DH-7, $\mathrm{DH}-9, \mathrm{DH}-9 \mathrm{~A}$, and $\mathrm{DH}-9 \mathrm{~B}$, were reentered and deepened to basalt. Core samples of the glaciofluviatile, the Ringold Formation, and the first underlying basalt flow were recovered. One new core hole was drilled, DH-8, which sampled three basalt flows and several interbeds.

These six holes provide a loose network of observation holes traversing the reservation in an east-west direction between the Columbia River and State Highway 240 (see plate). This program represents the first attempt to recover cores from the glaciofluviatile material and Ringold Formation beneath the Hanford Reservation.

\section{Purpose and Scope}

This report is a product of the continuing project aimed at quantifying the hydraulic parameters of the synthetic flow system of the Hanford Reservation (Summers and Deju, 1974, 1975). It deals with those features of the rocks that we observed in the cores. These features are of particular concern because they improve our understanding of fundamental lithologic and hydraulic properties of the sedimentary rocks, as they occur in the subsurface.

This is our basic-data report. It contains three parts:

(1) an introductory text describing our method of inspection and format for written description;

(2) summary logs that illustrate in condensed form the rocks penetrated by the wells drilled; and

(3) the detailed written descriptions of core samples.

This report deals with core samples from six wells representing 1348 feet of section within a total drilled depth of 1493 feet. The detailed descriptions provide geologists with data for a variety of interpretative programs; whereas, the summary logs provide a quick visual reference to the lithologic units.

\section{Sample Inventory}

The intent of a sample inventory was to find how much core at what depths remained intact for each well suite described. This serves two purposes. First, the recovery of a particular rock type is roughly proportional to the degree of its induration. Second, the inventory provides a ready reference for those scientists pursuing further tests that require intact cores. 
The cores are stored in heavy duty cardboard boxes that can contain as much as ten feet of intact core samples. All boxes are numbered sequentially; and each box gives the well number, the high and low core-run numbers, and the depth interval of core samples present in that box. The cores are permanently

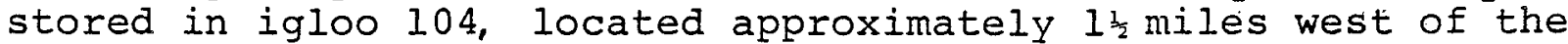
200 West Area.

All cores retrieved from these drill holes were immediately described and logged. Many of these remaining intact were wrapped in aluminum foil and sealed in paraffin. The logging geologist intended to preserve minerals as well as the physical integrity of the cores. Cores from below the water table are saturated with water and may crumble upon drying. They may contain minerals that oxidize upon drying. The dissolved solids in the water precipitate upon drying. Cores of unconsolidated rock crumbled immediately and were not sealed. The sealing process was fairly successful. Over 61 percent of the cored footage remained intact after coring, sealing, and transport as well as prolonged storage. Table 1 briefly reviews the recovery and survival rates for sediments and basalts by well. 
Table 1 -- Recovery and survival rates of cored sediments and basalts.

\begin{tabular}{|c|c|c|c|c|c|c|c|}
\hline Well & Number & $\begin{array}{r}\begin{array}{r}\text { Core } \\
\text { number }\end{array} \\
\text { from }\end{array}$ & $\frac{\begin{array}{c}\text { run } \\
\text { range }\end{array}}{\text { to }}$ & $\begin{array}{l}\text { Interval } \\
\text { cored (ft) }\end{array}$ & $\%$ Recovery & $\begin{array}{l}\% \text { of Recovery } \\
\text { still intact } \\
\end{array}$ & $\begin{array}{c}\text { Recovery footage } \\
\text { still intact }\end{array}$ \\
\hline \multirow[t]{2}{*}{$\mathrm{DH}-6$} & $\mathrm{~s}^{1}$ & 1 & 113 & 415 & 91 & 55 & 209 \\
\hline & $\mathrm{B}^{\mathrm{l}}$ & 114 & 115 & 10 & 100 & 100 & 10 \\
\hline \multirow[t]{2}{*}{$\mathrm{DH}-7$} & $\mathrm{~s}$ & 1 & 115 & 411 & 85 & 47 & 164 \\
\hline & $\mathrm{B}$ & 116 & 117 & 14 & 100 & 100 & 14 \\
\hline DH -8 & $\mathrm{~B}^{2}$ & 1 & 50 & 247 & 100 & 100 & 247 \\
\hline \multirow[t]{2}{*}{$\mathrm{DH}-9$} & $S$ & 1 & 29 & 68 & 90 & 27 & 17 \\
\hline & B & 30 & 32 & 19 & 100 & 100 & 19 \\
\hline \multirow[t]{2}{*}{$\mathrm{DH}-9 \mathrm{~A}$} & $\mathrm{~S}$ & 1 & 18 & 55 & 68 & 80 & 30 \\
\hline & $\mathrm{B}$ & 19 & 20 & 13 & 100 & 100 & 13 \\
\hline \multirow[t]{2}{*}{$\mathrm{DH}-9 \mathrm{~B}$} & $\mathrm{~s}$ & 1 & 55 & 243 & 92 & 81 & 182 \\
\hline & B & 56 & 57 & 9.5 & 100 & 100 & 9.5 \\
\hline
\end{tabular}

${ }^{1} \mathrm{~S}=$ Sediments; $\mathrm{B}=$ Basalts

${ }^{2}$ This well cored mostly basalt yet some thermally metamorphosed interbeds are also present. 
STUDY METHODS

Time and budget did not permit description of every sample in detail. We compiled the inventory and the macroscopic and microscopic descriptions of cores concommitantly.

\section{Descriptions}

We described the samples in a "down-hole" order. Every core was described in detail or, when the same as the previous core, noted as such. This expedited the description process by eliminating unnecessary duplicate descriptions. Fortunately, coring yields continuous samples and lithologic boundaries are clear. We handled each core only once. Samples were unsealed, when necessary, and resealed after description. We classified rocks as either sedimentary or volcanic.

\section{Volcanic Rocks}

Volcanic rocks appear in the samples both as trace fragments and as the major constituent. They occur in the Pasco Basin both as in-place massive, vesicular, and scoriaceous basalt flows, ash falls, and ash flows and as particles in the sedimentary rocks. The properties we described during the core examination were:

(1) volcanic rock type;

(2) degree of fracturing and weathering; and

(3) degree and types of fracture mineralization.

We recognized cores from in-situ basalt flows by the high core-recovery rates, fractures across vugs, and absence of weathering rinds. Vesicular lava flows still had minerals and mineraloids present in vugs. Fracture mineralization had not been replaced with clays, though most basalt flows we inspected had a weathered zone above the fresh basalt layer. Some "weathered zones" have the texture of mudflows.

Basalt and ash weathered in-place or from transport contain fragments with weathering rinds and often show leached phenocrysts (ex., plagioclase) and leached mineraloids on exterior surfaces. Transported fragments commonly appear rouncled or abraded. The composition of the basalt gravels ranged from exclusively basalt to subequal portions of "others" and basalt with a "salt and pepper" appearance.

\section{Sedimentary Rocks}

For the sedimentary rocks we recorded each rock type and:

(1) texture and composition;

(2) size range and shape; 
(3) quartz frosting;

(4) color;

(5) maturity;

(6) induration;

(7) trace fragments;

(8) fracture mineralization; and

(9) sedimentary fabric and structure.

Texture and composition. -- Texture refers to the particlesize distribution of granular material. We classified particle sizes according to the Wentworth Grade Scale and used a modified version of Folk's (1974) sediment classification (fig. 1) that was developed by Price and Fecht (1976) for use on the Hanford Reservation. To obtain an estimate of the particle-size distribution of the sample, during the core examination, we estimated the percentage of "fines," sand, and gravel. The "fines" included the silt and clay fractions. We divided both the sand and gravel into "basalt" and "other" and estimated the percent of each. Basalt gravel or sand consists of particles of basalt, whereas "other" gravel or sand consists of particles of other rock types, predominatly quartzite, gravels, and quartzose sands.

The gravel was inspected with the naked eye. Sand and fines were estimated at $10 \mathrm{x}$ microscope magnification. The use of low magnification ( $10 \mathrm{X}$ and $20 \mathrm{X}$ ) in this study prohibited identification of the clay- and silt-sized fractions individually.

Size range and shape. -- We described for the gravel and sand fractions their size range and roundness. Since quartzite and basalt were the two major contributors to the gravel fraction sphericity was ultraconstant. Quartz is the mineral we watch for the effects of transport in the sand range. It also has a consistently high to intermediate level of sphericity. We used visual estimates for determining both size range and shape. We reported the sand-gravel size range and the roundness of the quartz sand fraction.

Quartz frosting. -- Clear quartz is a common constituent of the "other" sands. It will appear with a frosted surface on the grains if it is from wind-transported sediments or if it is leached by meteoric solutions that favor the solution of silica. So for each "other" sand we noted the most abundant fraction of either frosted or unfrosted clear quartz. No note means that the amounts of each were not observable. 


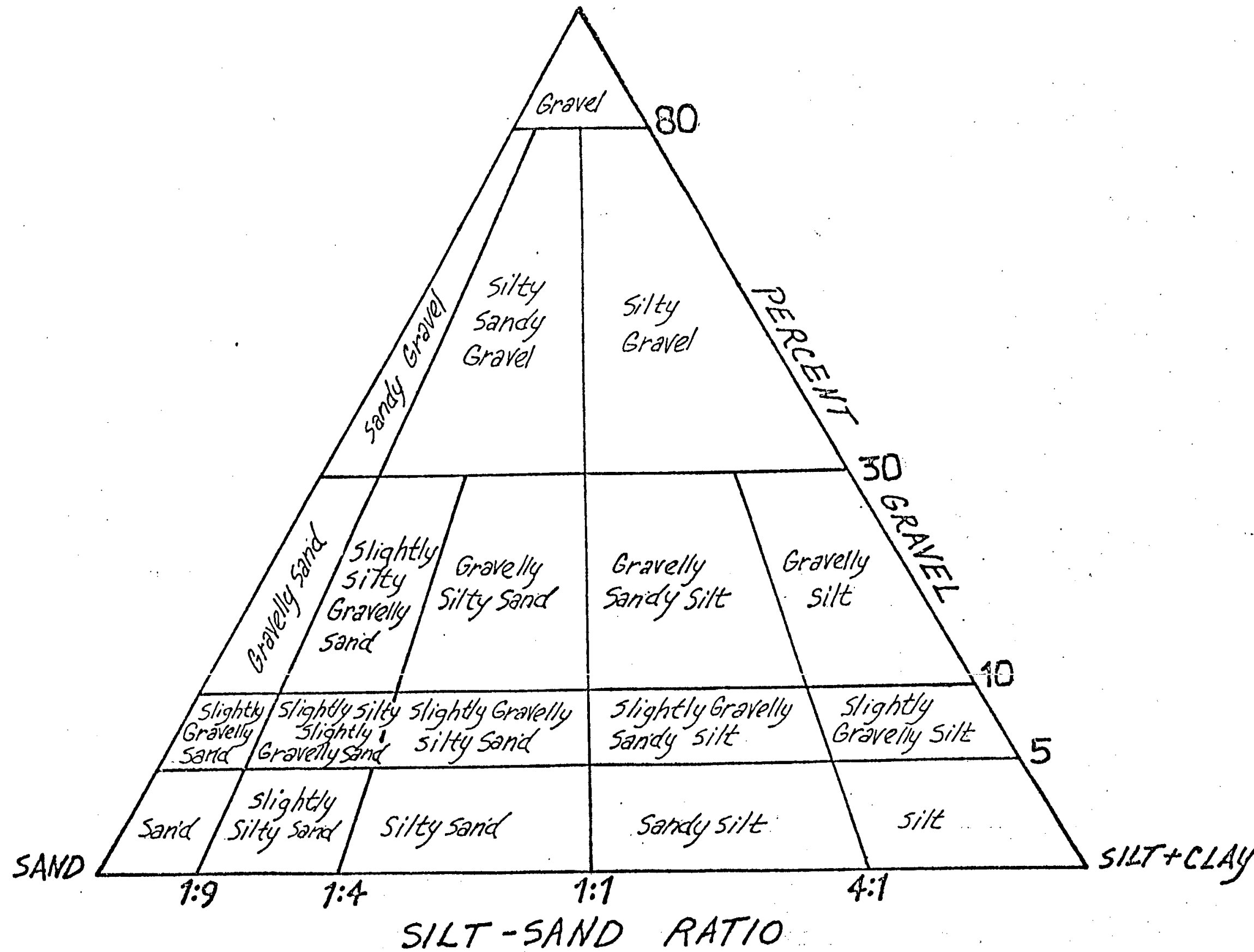

í

Figure 1.--Classification of clastic sedimentany rocks (PPICE and FECHT, 1976) 
Color. - The color we give in the description is the color of complete core material and reflects the mineral composition of that core interval. We recorded the color of each interval as it appears to the naked eye. Unlike drill cuttings the integrity of color in cores is very high and could be reliably used with other properties to distinguish between adjacent rock types.

In general the core-sample related to particle composition as follows :

(1) black and dark grays are due to basalt fragments;

(2) buffs, whites, and light grays are due to "other" fragments;

(3) browns, tans, yellows, blues, greens, and reds are due to the silt and clay component;

(4) whites, light yellows, and light tans are due to abundant caliche, diatomite, ash or quartz; and

(5) "salt and pepper" is due to equal to subequal amounts of basalt and "others" sand and/or gravel.

Maturity. -- We noted each rock interval's textural maturity (modified after Folk, 1974). This textural maturity definition is a measure of ability for a sediment to come to equilibrium with its transport environment before final deposition. Clean fluviatile gravels and sands and lacustrine clays are examples of sediments that are close to a mechanical equilibrium at time of deposition. The gravels and sand, for example, show good size sorting, good mineral and/or rock-fragment sorting, higher intergranular porosity, and commonly have rounded grains. Examples of immature sediments include fanglomerate and mudflows deposits. They show poor sorting, poor mineral and/or rockfragment segregation, low intergranular porosity, and commonly have angular grains.

Induration. -- We rated the induration of the rocks as unconsolidated, compacted, and lithified. Unconsolidated means grains were completely dissociated. Compacted means that cores occurred as friable aggregate clusters. Lithified means that the sample occurred in non-friable aggregate cores. Induration is a very prominent feature in core samples. Both the friability and interstitial fill are easily determined from core samples. Recovery and survival rates from sampling and storage also reflect the degree of induration. 
The degree of induration is governed by the presence of interstitial clays and cements. Less frequently the lack of sorting, certain types of fracture mineralization (for example, calcium carbonate), and thermal metamorphism (in some interbeds) also contribute to the tenacity of these sedimentary rocks.

Cements occur individually, with interstitial clays and silt, and in a variety of superimposed combinations of cements and "fines." They include silica and calcium carbonate, as well as reduced and oxidized iron minerals. We noted the response of the sample to a few drops of dilute hydrochloric acid.

Trace fragments. -- Several types of minerals and clastic debris significantly contribute to the group of distinguishing properties. Gypsum, mica, caliche, diatomaceous earth, pyroclastic rock particles, plus several unusual sedimentary clasts such as interclasts, intraclasts, and schistose boulders are recorded in our descriptions. Their presence and abundance fall in one of the following categories:

(1) not present,

(2) present $(1 \% \leq x<10 \%)$, and

(3) abundant $(x \geq 10 \%)$

These constituents have discrete (and in some cases mutually exclusive) environmental and/or transport regimes. Our genetic segregation between primary and secondary forms in core samples is very reliable. Though the presence of trace fragments is not uncommon, our ability to spot them is often hampered with intact cores due to the lack of surfaces available for scrutiny.

"Primary" forms appeared to us as angular and uncoated (i.e. unweathered) pebble-sized fragments. Pyroclastic rock fragments include ash, obsidian, and rhyolite shards. Primary gypsum appeared as euhedral to subhedral, unetched, sand sized crystals. This form of primary gypsum is consistent with Alimendinger and Titus's (1973) observation of primary gypsum forming in playa lake deposits in New Mexico.

"Secondary" forms show up as coated, rounded, and/or partially etched or dissolved pebble, sand, and silt sized grains of gypsum, diatomaceous earth, caliche, and volcanic ash shards.

Mica is always secondary and includes light and dark fragments. Most appear as degraded and/or abraded forms.

Fracture mineralization. -- Fractures were encountered in basalts and sedimentary rocks. When these fractures were filled, we recorded the types of minerals and clastic debris present. We also noted the degree and order of mineralization and mineral alteration. 
Sedimentary fabric and structure. -- We saw several fabrics and structures in the cores. These features (not seen in cuttings) aid in discriminating between adjacent, texturally identical rock types. Alluvial-fan deposits and tilloids are examples of "dirty" gravels. Palouse deposits, fluvial silts and lacustrine clayey silts are examples of "fines" with different origins.

Sedimentary petrographers define fabric as an arrangement or orientation or rock components. In this report we are concerned with those depositional or "primary" fabrics caused by various transport mechanisms and the resulting sequence and distribution (in time and space) of sedimentary grain textures, because no other fabrics can be seen in the cores. Imbrication, grain-size range and sorting and distribution of textures are examples of features affected by fluid transport. These, in turn, are closely linked to more general features such as porosity and induration. Interbedding of glaciofluviatile gravels and silts, lack of any bedding in the glaciofluviatile gravels, and rhythmic bedding in slack waters of proglacial Lake Lewis are examples of fabrics cited by Newcomb and others (1972) which we observed in the cores.

Sedimentary petrologists recognize three classes of structures in sedimentary rocks; mechanical, chemical, and organic. Mechanical or "primary" structures that we observed include graded bedding, laminations, mud cracks, interclasts, and intraclasts. Chemical or "secondary" structures we observed in cores include concretions, vugs, and veinlets. We also noted vug and veinlet fillings. Organic structures we observed included root casts and organic stains. In outcrops, Newcomb and others (1972) observed:

(1) interclasts along the erosional contact between the Ringold and glaciofluviatile sediment;

(2) channelization resulting in some erosional contacts between older and younger sediments; and

(3) an extensive caliche layer capping the Ringold Formation.

Persistent relief along some edges of the Pasco Basin caused certain alluvial fans to be the site of continual deposition since late Pleistocene time. At these sites no local erosional contact exist.

\section{Final Descriptive Log}

The description presented here derives from our preliminary description. We recorded these descriptions as a standard columnar format for sedimentary and volcanic rocks. 
Each table presents a title identifying the contents, well number, and location (when they are known). From left to right, each page contains:

(I) depth range of the interval;

(2) rock classification;

(3) core runs, percent recovery, and percent survival of the interval; and

(4) the rock type with a written description.

Written descriptions include all those features noted above.

$$
\text { Summary Log }
$$

Preceeding the descriptions for each well there is a summary log printed on $9 \times 11$ inch manila paper.

The oversized paper serves as an index tab, exposing the well number written along the length of the page in the upper right hand corner. On the summary log we give:

(1) routine information including

(a) plant coorainates,

(b) altitude, and -

(c) a listing of other data used in interpretation;

(2) a graphic log at a vertical scale of 1 inch $=50$ feet, that is split vertically into two parts (on the left is a percent basalt log and on the right is a lithologic log. Adjacent to the right side of the column are symbols disclosing the maturity, mica content, and the presence of frosting on clear quartz. Figure 2 displays the graphic and written symbols used on the summary logs); and

(3) written descriptive matter as required including color, fossils, trace constituents, total drilled depth, and any other nonstandard features observed. 


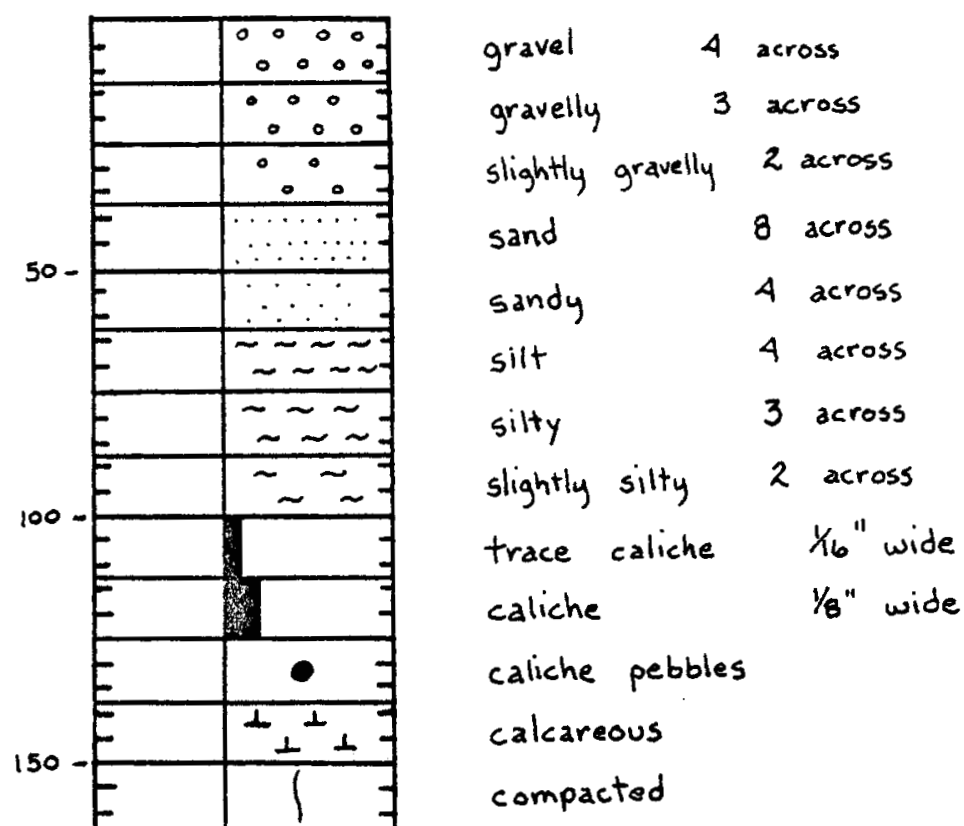

lithified

gypsiferous

slightly gypsiferous

basalt

no sample

\section{Figure 2}

Symbols Used on Summary Logs very mature

mature

sub-mature

micaceous

slightly micaceous

frosted

unfrosted 
Allmendinger, R.J. and Titus, F.B., 1973, Regional hydrology and evaporative discharge as a present-day source of gypsum at White Sands National Monument, New Mexico: N.M. State Bureau of Mines and Mineral Resources, Open file rept. OF-55, $53 \mathrm{p}$.

Deju, R.A. and summers, W.K., 1975, Transmissivity and hydraulic conductivity of saturated sedimentary rocks in the Hanford Reservation; CA-168-5, R.A. Deju and Associates Report to Atlantic Richfield Hanford Company under: ERDA Contract $\operatorname{AT}(45-1)-2120,41$ p.

Folk, Robert L., 1974, Petrology of sedimeritary rocks: Austin, Texas, Hemphill Publishing Company, 182 p.

Newcomb, R.C., Strand, J.R., and Frank, F.ir., 1972, Geology and ground-water characteristics of the Hanford Reservation of the U. S. Atomic Energy Commission, Washington: U.S. Geol. Surv., Prof. Paper 717, 78 p.

Price, W.H. and Fecht, K.R., 1976, Personal. Communication.

Summers, W.K. and Deju, R.A., 1974, A preliminary review of the regional hydrology of the Hanford Reservation; R.A. Deju and Associates Report to Atlantic Richfield Hanford Company under AEC Contract AT (45-1)-3140, 54 p. 
$\frac{\text { Depth }}{\text { (ft.) }}$

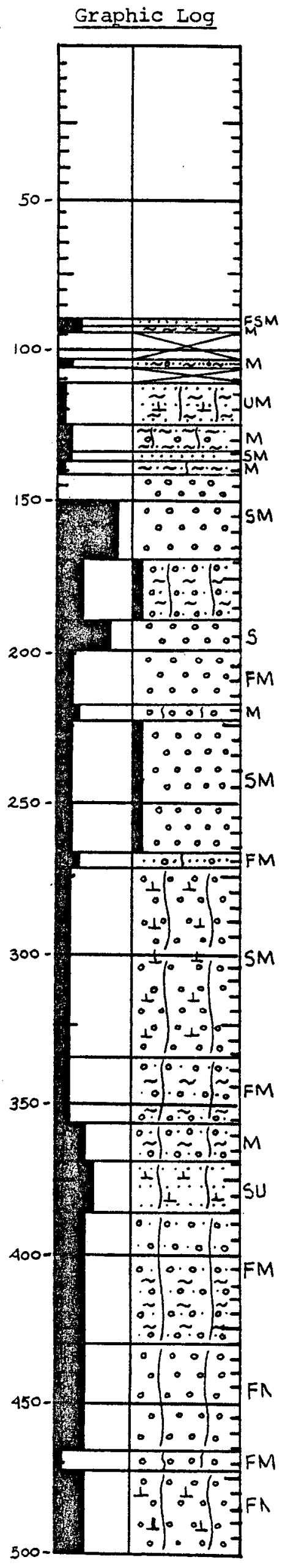

Sample Description

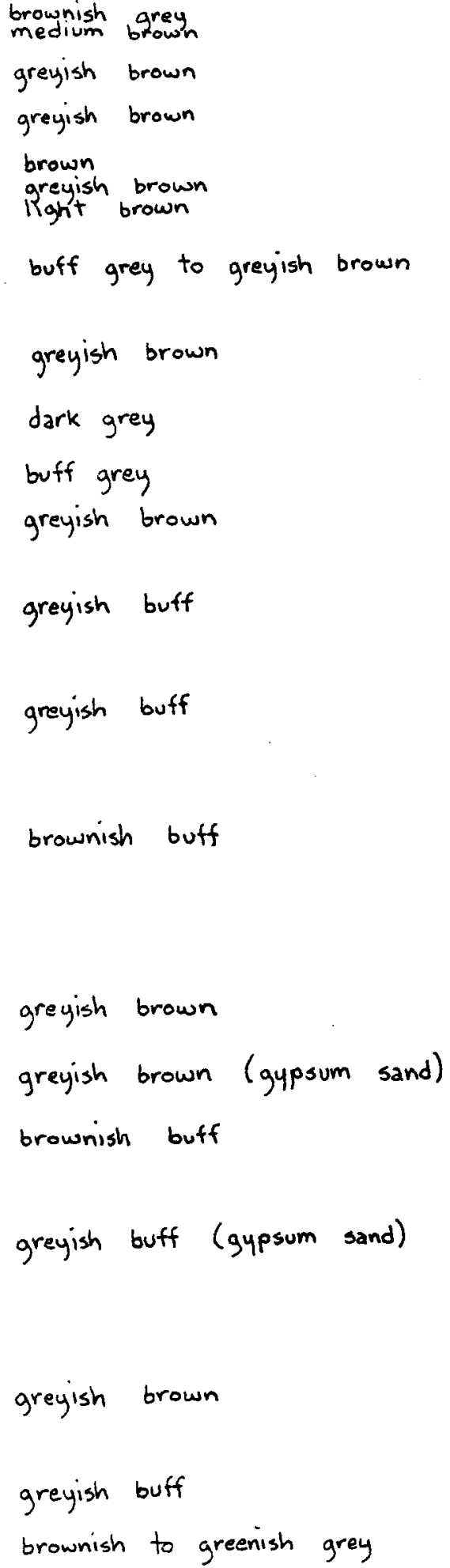

(1) driller's log

(2) geologist's log 
$\frac{\text { Depth }}{\text { (ft.) }}$

Graphic Log

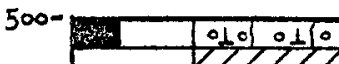

TD 515

F50

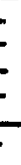

$E$

F

F

E

$E$

E

$E$

E

E

$E$

E

E

$E$

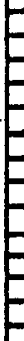

$E$

$E$

$E$

$E$

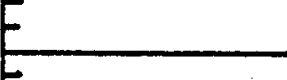

$E$

$E$

$E$

$E$

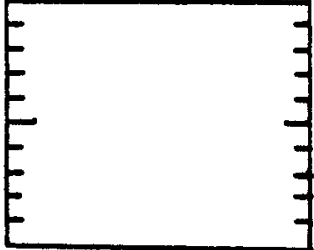

Altitude

Other Data used in Interpretation 
Table 2 -- Descriptive log of well no. DH-6 (299-W11-26, N043000, W075000) ${ }^{1}$.

1. personal communication with Roy Gephart, 8-19-76

\begin{tabular}{|c|c|c|c|c|c|c|}
\hline \multicolumn{3}{|c|}{ Depth (ft) } & \multicolumn{3}{|c|}{ Cores } & \multirow[b]{2}{*}{ Description } \\
\hline From & To & Classification & runs & orecovery & ointact & \\
\hline 90 & 93 & sand & 1 & 100 & 94 & $\begin{array}{l}\text { SAND, brownish gray, very fine to medium } \\
\text { sand, 63\% other sand (subrounded), } 34 \% \\
\text { basalt sand, and 3\% silt, unconsolidated, } \\
\text { frosted quartz, submature, fractured, mica- } \\
\text { ceous throughout }\end{array}$ \\
\hline 94 & 103 & & 2 & 0 & 0 & no sample \\
\hline 103 & 106 & $\begin{array}{l}\text { slightly } \\
\text { gravelly silty } \\
\text { sand }\end{array}$ & 3 & 100 & 83 & $\begin{array}{l}\text { SLIGHTLY GRAVELLY SILTY SAND, grayish } \\
\text { brown, very fine to very coarse sand, } 5 \% \\
\text { basalt gravel, } 56 \% \text { other sand (rounded), } \\
14 \% \text { basalt sand, and } 25 \% \text { silt and clay, un- } \\
\text { consolidated, immature, slightly calcareous, } \\
\text { fractured, micaceous throughout }\end{array}$ \\
\hline 106 & 111 & & 4 & 0 & 0 & no sample \\
\hline 111 & 125 & silty sand & $5-9$ & 76 & 75 & $\begin{array}{l}\text { SANDSTONE, grayish brown, very fine sand to } \\
\text { fine pebbles, } 1 \% \text { basalt gravel, } 58 \% \text { other } \\
\text { sand (subangular), 9\% basalt sand, and } 32 \% \\
\text { silt, unconsolidated to lithified by silt } \\
\text { and calcium carbonate, immature, unfrosted } \\
\text { quartz, fractured, micaceous throughout }\end{array}$ \\
\hline 125 & 134 & silty sand & $10-12$ & 67 & 67 & $\begin{array}{l}\text { SANDSTONE, brown, very fine sand to pebbles, } \\
2 \% \text { basalt gravel, } 64 \% \text { other sand (subangular), } \\
14 \% \text { basalt sand, and } 20 \% \text { silt, lithified by } \\
\text { silt and calcium carbonate, immature, frac- } \\
\text { tured, micaceous throughout }\end{array}$ \\
\hline
\end{tabular}




\begin{tabular}{|c|c|c|c|c|c|c|}
\hline \multicolumn{2}{|c|}{ Depth (ft) } & \multirow[b]{2}{*}{ Classification } & \multicolumn{3}{|c|}{ Cores } & \multirow[b]{2}{*}{ Description } \\
\hline From & To & & runs & srecovery & sintact & \\
\hline 134 & 137 & sand & 12 & 42 & 33 & $\begin{array}{l}\text { SAND, grayish brown, very fine to medium } \\
\text { sand, } 76 \% \text { other sand (subrounded), } 19 \% \\
\text { basalt sand, and } 5 \% \text { silt, unconsolidated, } \\
\text { fractured, submature, micaceous throughout }\end{array}$ \\
\hline 137 & 141 & sandy silt & 13 & 17 & 21 & $\begin{array}{l}\text { SANDY SILT, light brown, very fine to fine } \\
\text { sand, } 24 \% \text { other sand (subrounded), } 6 \% \\
\text { basalt sand, and } 70 \% \text { silt, compacted, frac- } \\
\text { tured, immature, micaceous throughout }\end{array}$ \\
\hline 141 & 169 & gravel & $14-29$ & 94 & 8 & $\begin{array}{l}\text { GRAVEL, buff gray to grayish brown, very } \\
\text { fine sand to boulders, } 21 \% \text { other gravel, } 73 \% \\
\text { basalt gravel, } 4 \% \text { other sand (subrounded), } \\
2 \% \text { basalt sand, unconsolidated, submature, } \\
\text { fractured, micaceous throughout }\end{array}$ \\
\hline 169 & 190 & $\begin{array}{l}\text { silty sandy } \\
\text { gravel }\end{array}$ & $30-34$ & 100 & 31 & $\begin{array}{l}\text { CONGLOMERATE, grayish brown, very fine sand } \\
\text { to small cobbles, 50\% other gravel, } 25 \% \\
\text { basalt gravel, } 12 \% \text { other sand (subrounded), } \\
8 \% \text { basalt sand, } 5 \% \text { silt and clay, compacted } \\
\text { to lithified by caliche, silt and clay, } \\
\text { fractured, immature, with a } 4 \text {-inch silt unit } \\
\text { capping this bed }\end{array}$ \\
\hline 190 & 199 & gravel & $35-40$ & 100 & 0 & $\begin{array}{l}\text { GRAVEL, dark gray, very fine sand to large } \\
\text { cobbles, } 27 \% \text { other gravel, } 68 \% \text { basalt } \\
\text { gravel, } 2 \% \text { other sand (well rounded), } \\
1 \% \text { basalt sand, and } 2 \% \text { silt and clay, uncon- } \\
\text { solidated, submature, fractured }\end{array}$ \\
\hline 199 & 218 & gravel & $41-45$ & 92 & 51 & $\begin{array}{l}\text { GRAVEL, buff gray, very fine sand to } \\
\text { boulders, } 68 \% \text { other gravel, } 18 \% \text { basalt } \\
\text { gravel, } 10 \% \text { other sand (subrounded), } 4 \% \\
\text { basalt sand, unconsolidated, frosted quartz, } \\
\text { immature, with iron oxide stains, fractured, } \\
\text { a few iron concretions, micaceous throughout }\end{array}$ \\
\hline
\end{tabular}


Table 2 -- Descriptive $\log$ of well no. DII-6 cont

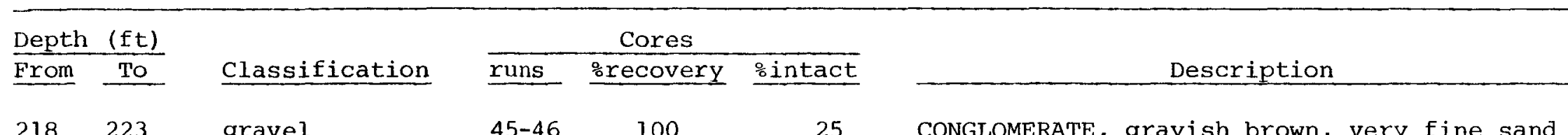

$\begin{array}{llllll}218 & 223 & \text { gravel } & 45-46 & 100 & 25\end{array}$

CONGLOMERATE, grayish brown, very fine sand to small cobbles, 59\% other gravel, 25\% basalt gravel, 10\% other sand (subrounded), 2\% basalt sand, and $4 \%$ silt and clay, lithified by iron minerals, silt, and clay, immature, fractured, iron concretions present, micaceous throughout

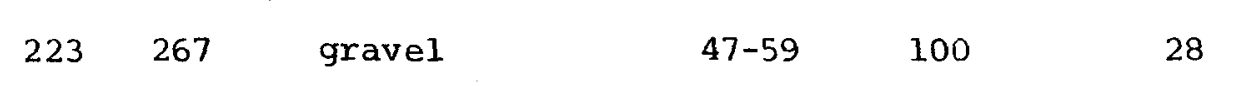

GRAVEL, grayish buff, very fine sand to boulder, $78 \%$ other gravel, $15 \%$ basalt gravel, 5\% other sand (subrounded), 1\% basalt sand, and $1 \%$ silt and clay, compacted to unconsolidated, iron oxide and caliche coatings, fractured, iron concretions 223-255, unfrosted and frosted quartz, submature, micaceous throughout

$\begin{array}{llllll}267 & 272 & \text { sandy gravel } & 60 & 100 & 68\end{array}$

SANDY GRAVEL, grayish buff, medium sand to small cobbles, $20 \%$ other gravel, $20 \%$ basalt gravel, 48\% other sand (subrounded), ara $12 \%$ basalt sand, compacted, frosted quartz, immature, fractured, micaceous throughout

CONGLOMERATE, brownish buff, very fine sand to boulders, $66 \%$ other gravel, 17\% basalt grave1, 13\% other sand (subrounded), 2\% basalt sand, and $2 \%$ silt and clay, lithified by iron oxide minerals, silt and clay, trace of disseminated calcium carbonate, submature, subequal frosted and unfrosted quartz, iron concretions present, fractured, micaceous throughout 
Table 2 -- Descriptive log of well no. DH-6 cont

\begin{tabular}{|c|c|c|c|c|c|c|}
\hline \multicolumn{3}{|c|}{ Depth (ft) } & \multicolumn{3}{|c|}{ Cores } & \multirow[b]{2}{*}{ Description } \\
\hline From & To & Classification & runs & orecovery & sintact & \\
\hline 335.5 & 356.5 & $\begin{array}{l}\text { silty sandy } \\
\text { gravel }\end{array}$ & $78-83$ & 95 & 29 & $\begin{array}{l}\text { CONGLOMERATE, grayish brown, very fine sand } \\
\text { to large cobbles, } 54 \% \text { other gravel, 19\% } \\
\text { basalt gravel, } 16 \% \text { other sand (subrounded), } \\
4 \% \text { basalt sand, and } 7 \% \text { silt and clay, lith- } \\
\text { ified by iron oxides, silt, and clay, im- } \\
\text { mature, frosted quartz, fractured, iron con- } \\
\text { cretions present, micaceous throughout }\end{array}$ \\
\hline 356.5 & 369 & $\begin{array}{l}\text { silty sandy } \\
\text { gravel }\end{array}$ & $83-86$ & 97 & 67 & $\begin{array}{l}\text { CONGLOMERATE, grayish brown, very fine sand } \\
\text { to boulders, } 47 \% \text { other gravel, } 33 \% \text { basalt } \\
\text { gravel, } 13 \% \text { other sand, } 3 \% \text { basalt sand, and } \\
4 \% \text { silt and clay, lithified by iron oxides, } \\
\text { silt and clay, fractured, immature, gypsum } \\
\text { sand present } 356.5-358 \text {, with iron concretion } \\
\text { present, micaceous throughout }\end{array}$ \\
\hline 369 & 386 & sand & $86-89$ & 96 & 95 & $\begin{array}{l}\text { SANDSTONE, brownish buff, very fine sand to } \\
\text { very coarse sand, } 47 \% \text { other sand (subrounded), } \\
48 \% \text { basalt sand, and } 5 \% \text { silt and clay, } \\
\text { lithified by silt and clay, and disseminated } \\
\text { calcium carbonate, sibmature, unfrosted } \\
\text { quartz present }\end{array}$ \\
\hline 386 & 430 & $\begin{array}{l}\text { silty sandy } \\
\text { gravel }\end{array}$ & $89-98$ & 90 & 73 & $\begin{array}{l}\text { CONGLOMERATE, grayish buff, very fine sand } \\
\text { to very coarse pebbles, } 43 \% \text { other gravel, } \\
36 \% \text { basalt gravel, } 12 \% \text { other sand (subangular) } \\
4 \% \text { basalt sand, and } 5 \% \text { silt and clay, lith- } \\
\text { ified by iron oxides, silt, and clay, im- } \\
\text { mature, some fractures present, frosted } \\
\text { quartz, gypsum sand present } 408-411.5, \\
\text { micaceous throughout }\end{array}$ \\
\hline
\end{tabular}

silty sandy gravel

silty sandy 
Table 2 -- Descriptive log of well no. DH-6 cont

\begin{tabular}{|c|c|c|c|c|c|c|}
\hline \multicolumn{3}{|c|}{ Depth (ft) } & \multicolumn{3}{|c|}{ Cores } & \multirow[b]{2}{*}{ Description } \\
\hline From & To & Classification & runs & orecovery & sintact & \\
\hline 430 & 466 & gravel & $98-105$ & 98 & 64 & $\begin{array}{l}\text { CONGLOMERATE, grayish brown, very fine sand } \\
\text { to boulders, } 51 \% \text { other gravel, } 34 \% \text { basalt } \\
\text { gravel, } 9 \% \text { other sand (subrounded), 1\% } \\
\text { basalt sand, and 5\% silt and clay, lithified } \\
\text { by iron oxides, silt, and clay, immature, } \\
\text { frosted quartz, some fractures present, } \\
\text { slightly micaceous }\end{array}$ \\
\hline 466 & 472 & gravel & $105-106$ & 100 & 69 & $\begin{array}{l}\text { CONGLOMERATE, grayish buff, very fine sand } \\
\text { to small cobbles, } 78 \% \text { other grave1, } 7 \% \\
\text { basalt gravel, } 9 \% \text { other sand (subangular), } \\
1 \% \text { basalt sand, and 5\% silt, lithified by } \\
\text { iron oxides, silt, and clay, immature, some } \\
\text { fractures present, frosted quartz, iron con- } \\
\text { cretions present, micaceous throughout }\end{array}$ \\
\hline 472 & 505 & gravel & $107-113$ & 99 & 72 & $\begin{array}{l}\text { CONGLOMERATE, brown to greenish gray, very } \\
\text { fine sand to boulders, } 38 \% \text { other gravel, } 43 \% \\
\text { basalt gravel, } 9 \% \text { other sand (subrounded), } \\
\text { l\% basalt sand, and } 9 \% \text { silt and clay, lith- } \\
\text { ified by disseminated calcium carbonate, } \\
\text { silt, anc clay, some fractures present, im- } \\
\text { mature, frosted quartz, faint imbrication } \\
\text { present, slightly micaceous }\end{array}$ \\
\hline 505 & 515 & basalt & $114-115$ & 100 & 100 & $\begin{array}{l}\text { BASALT, black, vesicular, fractured, frac- } \\
\text { tures filled with silt and clay, weathered } \\
\text { basalt zone greater than } 5 \text { feet thick with } \\
\text { mineraloids still in vugs throughout }\end{array}$ \\
\hline
\end{tabular}


$\frac{\text { Depth }}{\text { (ft.) }}$

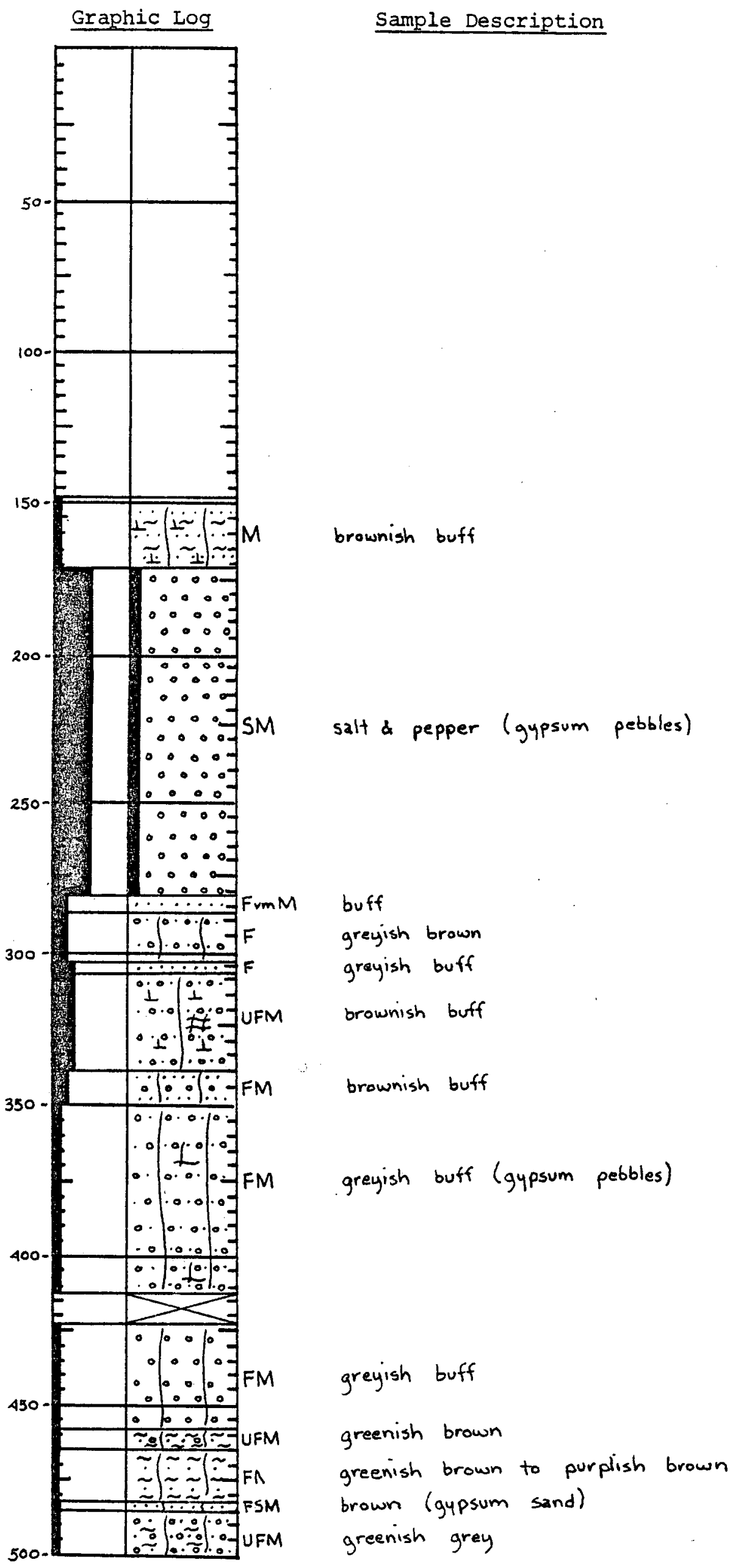

Plant Coordinates

\begin{tabular}{l}
$N \quad 075000$ \\
$W \quad 037000$ \\
\hline Altitude
\end{tabular}

Other Data used in Interpretation

(1) driller's log
(2) geologist's log 
Table 3 -- Descriptive log of well no. DH-7 (299-W19-10, N037000, w075000) ${ }^{1}$.

1. personal communication with Roy Gephart, 8-19-76

\begin{tabular}{|c|c|c|c|c|c|c|}
\hline Depth & $(f t)$ & & & Cores & 1 & \\
\hline From & To & Classification & runs & srecovery & ointact & Description \\
\hline
\end{tabular}

$148 \quad 171$

$171 \quad 281$

gravel

$5-48$

93

281

287

sand

sandy gravel

$50-53$

73

$287 \quad 303$

sandy gravel

sand

$53-54$

67

24

50

39

303
.
SANDSTONE, brownish buff, very fine to very coarse sand, 40\% other sand (angular), $11 \%$ basalt sand, 49\% silt and clay, lithified by calcium carbonate, silt, and clay, micaceous, immature, caliche veins and fragments present

GRAVEL, "salt and pepper," silt to boulders, $44 \%$ other grave1, 46\% basalt gravel, $1 \%$ basalt sand, and 9\% other sand (well rounded) and silt, compacted to unconsolidated, submature, 6-inch caliche zone within 225-227, gypsum pebbles present 242-244, micaceous throughout sandy portions SAND, buff, well rounded, medium to coarse sand, $80 \%$ other sand (well rounded), and $20 \%$ basalt sand, unconsolidated, very mature, frosted quartz, micaceous throughout

CONGLOMERATE, grayish brown, very fine sand to boulders, 55\% other gravel, 13\% basalt gravel, 26\% other sand (well rounded), and 6\% basalt sand, lithified, frosted quartz, immature

SAND, grayish buff, very fine sand to boulders (?), 5\% basalt gravel, 65\% other sand (subrounded), 29\% basalt sand, and 1\% silt and clay, unconsolidated, immature, frosted quartz, trace of gypsum (?) present 
Table 3 -- Descriptive log of well no. DH-7 cont

\begin{tabular}{|c|c|c|c|c|c|c|}
\hline \multirow{2}{*}{$\begin{array}{l}\text { Depth } \\
\text { From }\end{array}$} & \multirow{2}{*}{$\frac{(\mathrm{ft})}{\mathrm{TO}}$} & \multirow[b]{2}{*}{ Classification } & \multicolumn{3}{|c|}{ Cores } & \multirow[b]{2}{*}{ Description } \\
\hline & & & runs & :recovery & ointact & \\
\hline 307 & 340 & sandy gravel & $54-63$ & 74 & 32 & $\begin{array}{l}\text { CONGLOMERATE, brownish buff, very fine sand } \\
\text { to pebbles, 50\% other grave1, } 23 \% \text { basalt } \\
\text { gravel, 19\% other sand (well rounded), 6\% } \\
\text { basalt sand, and less than } 2 \% \text { clay } \\
\text { (bentonite?), compacted with some calcium } \\
\text { carbonate cement present, immature, unfrost- } \\
\text { ed quartz, massive gypsum } 310-313 \text {, schist } \\
\text { pebbles } 335-340 \text {, micaceous throughout }\end{array}$ \\
\hline
\end{tabular}

$\begin{array}{llllll}340 & 350 & \text { gravelly sand } & 64-65 & 71 & 63\end{array}$

350

413

sandy gravel

$66-81$

80

32

$413 \quad 423$

$423 \quad 458$

gravel

$82-83$

0

$84-94 \quad 79$

SANDSTONE, brownish buff, very fine sand to pebbles, 14\% other gravel, 5\% basalt gravel, $68 \%$ other sand (subrounded), $12 \%$ basalt sand, and less than $1 \%$ silt, lithified, frosted quartz, micaceous throughout

CONGLOMERATE, grayish buff, very fine sand to small cobbles, $67 \%$ other gravel, $11 \%$ basalt gravel, 17\% other sand (rounded), 3\% basalt sand, and $2 \%$ silt and clay, immature, lithified by iron oxides, frosted quartz, iron concretions 350-392 and 406-413, fibrous gypsum present 395-398, gypsum pebbles present 402-406, micaceous throughout

no sample

CONGLOMERATE, grayish buff, very fine sand to very coarse pebbles, $80 \%$ other gravel, 9\% basalt gravel, $8 \%$ other sand (rounded), $2 \%$ basalt sand, and $1 \%$ silt and clay, lithified by iron oxides, silt, and clay, immature, frosted quartz, iron concretions present 423-453, exotic volcaniclastics present 437-458, micaceous throughout 
Table 3 -- Descriptive log of well no. DH-7 cont

\begin{tabular}{|c|c|c|c|c|c|c|}
\hline \multicolumn{3}{|c|}{ Depth (ft) } & \multicolumn{3}{|c|}{ Cores } & \multirow[b]{2}{*}{ Description } \\
\hline From & To & Classification & runs & orecovery & intact & \\
\hline 458 & 465 & $\begin{array}{l}\text { slightly } \\
\text { gravelly } \\
\text { sandy silt }\end{array}$ & $94-95$ & 94 & 90 & $\begin{array}{l}\text { MUDSTONE, greenish brown, very fine sand to } \\
\text { very coarse pebbles, } 7 \% \text { other gravel, } 14 \% \\
\text { other sand (subangular), 5\% basalt sand, } \\
\text { and } 74 \% \text { silt and clay, lithified by iron } \\
\text { oxides, silt, and clay, fractured, immature, } \\
\text { unfrosted quartz, micaceous throughout }\end{array}$ \\
\hline 482 & 485 & sand & 99 & 100 & 44 & $\begin{array}{l}\text { SANDSTONE, brown, angular, very fine to } \\
\text { coarse sand, } 88 \% \text { other sand (angular), } 10 \% \\
\text { basalt sand, and } 2 \% \text { silt, lithified by silt, } \\
\text { frosted quartz, fractured, gypsum sand present } \\
482-484 \text {, submature, micaceous throughout }\end{array}$ \\
\hline 485 & 523 & $\begin{array}{l}\text { silty sandy } \\
\text { gravel }\end{array}$ & $100-107$ & 99 & 61 & $\begin{array}{l}\text { CONGLOMERATE, greenish gray, very fine sand } \\
\text { to boulders, } 71 \% \text { other gravel, } 11 \% \text { basalt } \\
\text { gravel, } 12 \% \text { other sand (well rounded), 3\% } \\
\text { basalt sand, and } 3 \% \text { silt and clay, lithified } \\
\text { by iron oxides, silt, and clay, immature, } \\
\text { unfrosted quartz, micaceous throughout }\end{array}$ \\
\hline 523 & 548 & sandy gravel & $108-113$ & 98 & 48 & $\begin{array}{l}\text { CONGLOMERATE, gray "salt and pepper," very } \\
\text { fine sand to boulders, } 27 \% \text { other gravel, } 54 \% \\
\text { basalt gravel, } 14 \% \text { other sand (well rounded), } \\
2 \% \text { basalt sand, } 3 \% \text { silt and clay, immature, } \\
\text { lithified by iron oxides, silt, and clay, } \\
\text { unfrosted quartz, iron concretions present, } \\
\text { micaceous throughout }\end{array}$ \\
\hline
\end{tabular}


Table 3 -- Descriptive log of well no. DH-7 cont

\begin{tabular}{|c|c|c|c|c|c|c|}
\hline \multicolumn{2}{|c|}{ Depth (ft) } & \multirow[b]{2}{*}{ Classification } & \multicolumn{3}{|c|}{ Cores } & \multirow[b]{2}{*}{ Description } \\
\hline From & To & & runs & orecovery & ointact & \\
\hline 548 & 554 & sand & $113-114$ & 97 & 11 & $\begin{array}{l}\text { SAND, greenish gray very fine to very } \\
\text { coarse sand, } 65 \% \text { other sand (rounded), } 35 \% \\
\text { basalt sand, mature, unconsolidated, } \\
\text { frosted quartz, micaceous throughout }\end{array}$ \\
\hline 554 & 559 & $\begin{array}{l}\text { silty sandy } \\
\text { gravel }\end{array}$ & 115 & 58 & 52 & $\begin{array}{l}\text { CONGLOMERATE, green to black, very fine } \\
\text { sand to boulders, } 16 \% \text { other gravel, } 64 \% \\
\text { basalt gravel, } 6 \% \text { other sand (very angular) } \\
4 \% \text { basalt sand, and } 10 \% \text { silt and clay, } \\
\text { lithified by silt and clay, immature, } \\
\text { frosted quartz, micaceous throughout }\end{array}$ \\
\hline 559 & 573 & basalt flow & $116-118$ & 100 & $<100$ & $\begin{array}{l}\text { BASALT, black, vesicular, fractured, with } \\
\text { first } 5.5 \text { feet weathered zone and remainder } \\
\text { "fresh" basalt, mineraloids in vugs, clay } \\
\text { filled fractures throughout }\end{array}$ \\
\hline
\end{tabular}




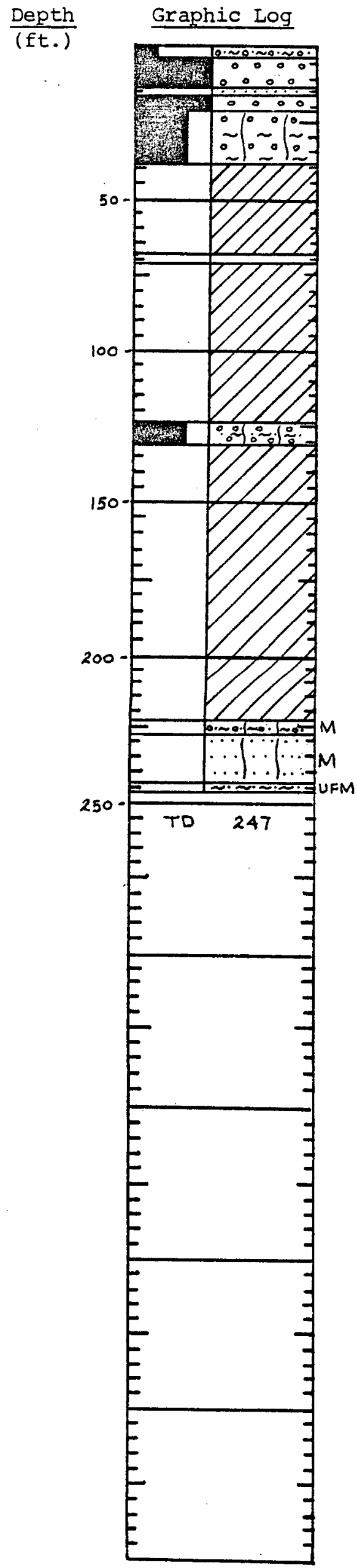

Sample Description

reddish brown, green \& grey mottled

black

reddish brown to greyish green

reddish brown to greyish green (ANHYDRITE)

Altitude 460

$\mid \begin{aligned} & n \\ & 0 \\ & 0\end{aligned}$

$\mid \begin{aligned} & 0 \\ & 0 \\ & 0\end{aligned}$

10

green

Other Data used in

Interpretation
(1) driller's Log
(2) geologist's Log

reddish brown to black

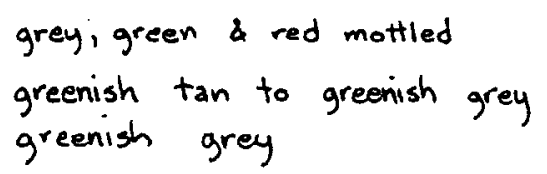


Table 4 -- Descriptive $\log$ of well no. DH-8 [699-61-55 (DH-8A) $]^{1}$

1. personal communication with Roy Gephart, 8-19-76

\begin{tabular}{|c|c|c|c|c|c|c|}
\hline Depth & $(\mathrm{ft})$ & & & Cores & & \\
\hline From & To & Classification & runs & orecovery & ointact & Description \\
\hline 0 & 3.5 & $\begin{array}{l}\text { silty sandy } \\
\text { gravel }\end{array}$ & 1 & 100 & $\leq 100$ & $\begin{array}{l}\text { CONGLOMERATE, reddish brown, green, and gray } \\
\text { mottled, very fine sand to boulders, } 30 \% \\
\text { basalt gravel, 30\% sano (subangular), and } \\
40 \% \text { silt and clay, lithified by a mild } \\
\text { thermal metamorphism, lacks bedding }\end{array}$ \\
\hline 3.5 & 14 & gravel (?) & $1-2$ & 100 & $\leq 100$ & $\begin{array}{l}\text { BOULDER (?), black, fractured, vesicular } \\
\text { basalt with secondary, crystalline quartz in } \\
\text { vugs }\end{array}$ \\
\hline 14 & 16 & sand & 2 & 100 & $\leq 100$ & $\begin{array}{l}\text { SANDSTONE, reddish brown to grayish green, } \\
\text { hornfelsic, lithified with crystalline } \\
\text { quartz in vugs }\end{array}$ \\
\hline 16 & 21 & gravel (?) & $2-3$ & 100 & $\leq 100$ & $\begin{array}{l}\text { BOULDER (?), black, vesicular basalt with } \\
\text { secondary, crystalline quartz in vugs }\end{array}$ \\
\hline 21 & 39 & silty gravel & $3-6$ & 100 & $\leq 100$ & $\begin{array}{l}\text { CONGLOMERATE, reddish brown to greenish } \\
\text { gray, clay to boulders, hornfelsic with } \\
\text { crystalline quartz in vugs, clay interclasts, } \\
\text { anhydrite present, gravel is exclusively } \\
\text { vesicular basalt }\end{array}$ \\
\hline 39 & 68 & basalt & $7-12$ & 100 & 100 & $\begin{array}{l}\text { BASALT, gray, massive to fractured, } \\
\text { with baked, clay, fracture fill grading } \\
\text { from no fill to black hornfelsic fill in } \\
\text { less fractured basalt }\end{array}$ \\
\hline 68 & 71 & silt & $12-13$ & 100 & 100 & CLAY, green, mildly baked yet lithified \\
\hline 71 & 124 & basa1t & $13-25$ & 100 & 100 & $\begin{array}{l}\text { BASALT, black, massive, fractured, with } \\
\text { black, vitreous, very fine grained to } \\
\text { hornfelsic fracture fill sporadically } \\
\text { occurring between zones of clean fractures, } \\
\text { few to no fractures with a trace of copper } \\
\text { minerals, possibly chrysocolla, at bottom } \\
\text { of flow }\end{array}$ \\
\hline
\end{tabular}




\begin{tabular}{|c|c|c|c|c|c|c|}
\hline \multicolumn{3}{|c|}{ Depth (ft) } & \multicolumn{3}{|c|}{ Cores } & \multirow[b]{2}{*}{ Description } \\
\hline From & To & Classification & runs & grecovery & gintact & \\
\hline 124 & 131 & $\begin{array}{l}\text { silty sandy } \\
\text { gravel }\end{array}$ & $25-26$ & 100 & 100 & $\begin{array}{l}\text { RUBBLE ZONE, reddish brown to black, baked, } \\
\text { made of scoriaceous to vesicular klinker and } \\
\text { flow fragments in a silt-clay matrix, copper } \\
\text { mineralization is present along fractures } \\
\text { and in vugs }\end{array}$ \\
\hline 131 & 223 & basalt & $26-45$ & 100 & 100 & $\begin{array}{l}\text { BASALT, black, vesicular, vitreous, frac- } \\
\text { tured, with filled fractures at } 131-156 \text { and } \\
\text { at } 161-176 \text {, clean or partially mineralized } \\
\text { fractures complete the flow interval as } \\
\text { follows: 156-161 (bornite); 176-191; 191- } \\
213 \text { (thin, dark green coatings); } 213-218 \\
\text { euhedral pyrite); and } 218-223 \text { (euhedral } \\
\text { quartz), apparent autobreccia zone at 154- } \\
156\end{array}$ \\
\hline 223 & 228 & $\begin{array}{l}\text { silty sandy } \\
\text { gravel }\end{array}$ & 46 & 100 & 100 & 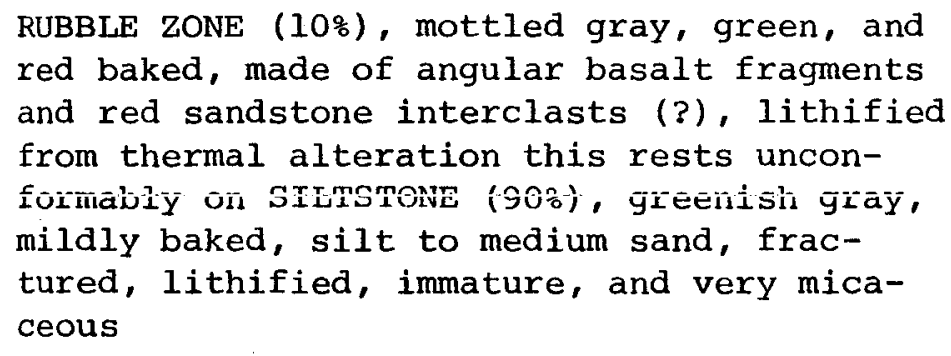 \\
\hline 228 & 244.5 & sand & $47-50$ & 100 & 100 & $\begin{array}{l}\text { SANDSTONE, greenish tan to greenish gray, } \\
\text { very fine sand to very coarse sand sized, } \\
\text { greater than } 10 \% \text { silt and clay, immature, } \\
\text { mildly baked, lithified, micaceous and } \\
\text { tuffaceous throughout }\end{array}$ \\
\hline 244.5 & 247 & sandy silt & 50 & 100 & 100 & $\begin{array}{l}\text { MUDSTONE, greenish gray, mildly baked, } \\
\text { tuffaceous, less than } 25 \% \text { sand, } 75 \% \text { silt } \\
\text { and clay, very fine to very coarse sand, } \\
\text { immature, lithified, with angular unfrosted } \\
\text { quartz present, micaceous throughout }\end{array}$ \\
\hline
\end{tabular}




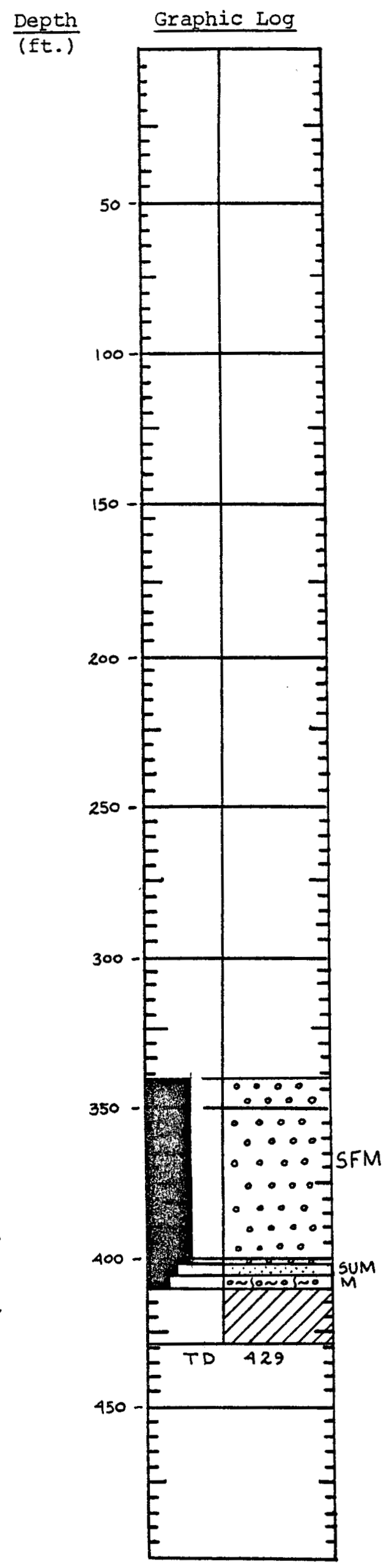

Sample Description

Plant Coordinates

$N .049426$

$\frac{W \quad 100348}{\text { Altitude } 793}$

Other Data used in Interpretation

(1) driller's $\log$

(2) geologist's log greyish brown

grey (salt \& pepper)
tan to yellowish grey

first 10' weathered basalt 
Table 5 -- Descriptive log of well no. DH-9 (699-49-100A, N049426, W100348, 792.6 feet $^{\left.\mathrm{msl}^{1}\right)^{2}}$

1. casing elevation

2. personal communication with Roy Gephart, 11-20-75

Depth (ft)

$\begin{array}{lllll}342 & 402.5 & \text { gravel } & 1-26 & 89\end{array}$

402.5406

sand

406 410

silty gravel

$27-28$

100

$28-32$

100

\section{Description}

GRAVEL, grayish brown, very fine sand to boulders, $21 \%$ other gravel, $60 \%$ basalt gravel, $10 \%$ other sand (rounded), $1 \%$ basalt sand, and $8 \%$ silt and clay, unconsolidated to lithified, submature, frosted grading to unfrosted quartz, micaceous throughout, cemented by silt and clay and a minor amount of iron oxide minerals, gypsum sand present $393-402.5$

SAND, "salt and pepper," very fine sand to fine pebbles, $1 \%$ other gravel, $4 \%$ basalt gravel, 54\% other sand (subangular), 36\% basalt sand, and 5\% silt and clay, unconsolidated, unfrosted quartz, submature, micaceous throughout

CONGLOMERATE (interbedded), tan to yellowish gray, very rine sand to very coarse pebiles, $27 \%$ other gravel, $30 \%$ basalt gravel, $4 \%$ other sand (subrounded), $2 \%$ basalt sand, and $37 \%$ silt and clay, sequence of interbedded gravelly silts and clays, and silty gravels, lithified by silt and clay, fractured, immature, micaceous throughout

BASALT, gray to black, fractured, vesicular to massive, first 10 feet weathering zone with silt-clay fracture fill and remaining 19 feet shows iron oxides in fractures, no mineraloids in vugs except in bottom foot, 428-429 
$\frac{\text { Depth }}{\text { (ft.) }}$

Graphic Log Sample Description

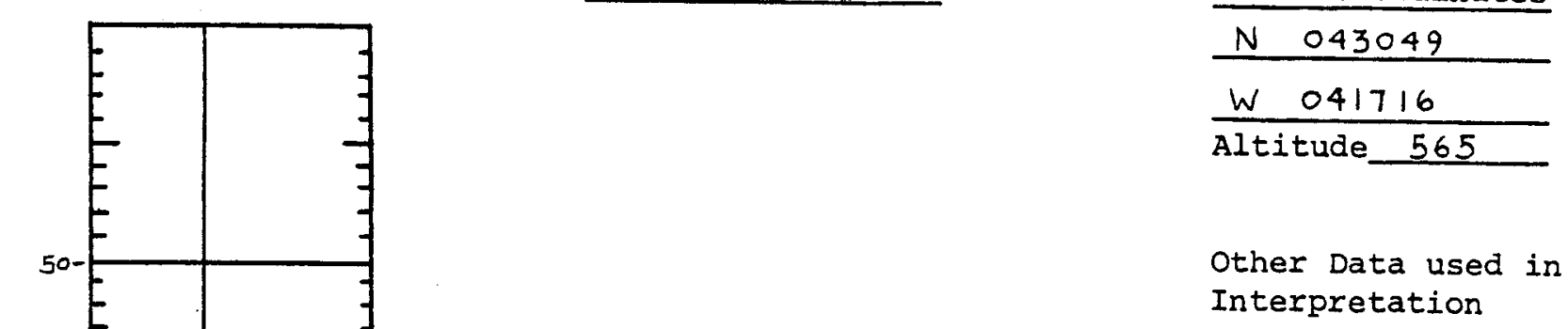

(1) driller's Log

(2) geologist's Log

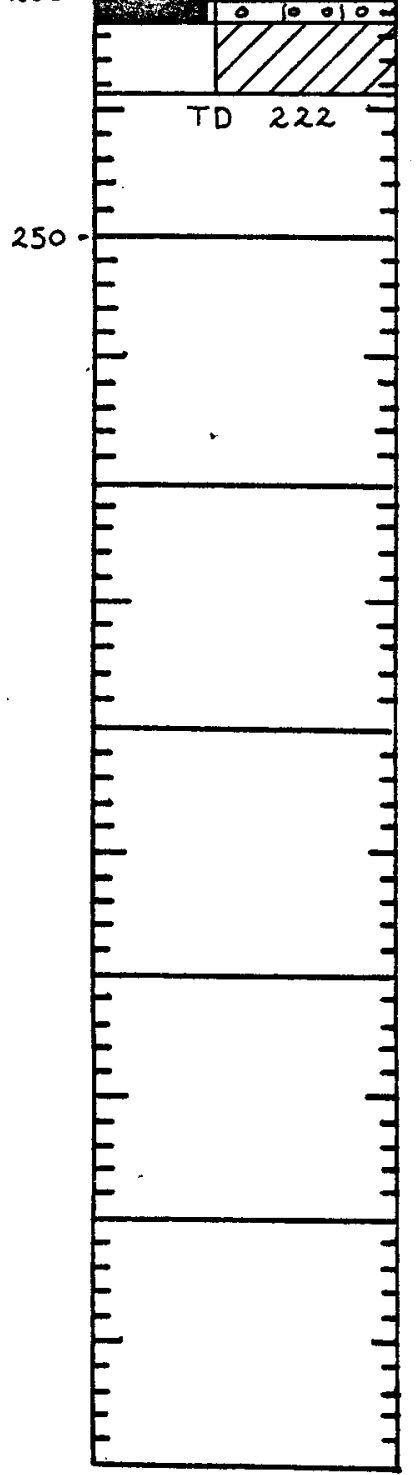


Table 6 -- Descriptive log of well no. DH-9A (699-43-42, N043049, W041716, 564.48 feet msl ${ }^{1}$, Hanford Wells, 1973).

1. casing elevation

\begin{tabular}{|c|c|c|c|c|c|c|}
\hline \multicolumn{3}{|c|}{ Depth (ft) } & \multicolumn{3}{|c|}{ Cores } & \multirow[b]{2}{*}{ Description } \\
\hline From & To & Classification & runs & srecovery & sintact & \\
\hline 154 & 185 & gravel & $1-12$ & 56 & 19 & $\begin{array}{l}\text { GRAVEL, grayish brown, very fine sand to } \\
\text { large cobbles, 58\% other gravel, 27\% basalt } \\
\text { gravel, and } 15 \% \text { sand, silt, and clay, uncon- } \\
\text { solidated to compacted, immature, fractures } \\
\text { present, micaceous throughout, with some } \\
\text { current graded bedding 157-159 }\end{array}$ \\
\hline 185 & 197 & silt & $13-15$ & 77 & 76 & $\begin{array}{l}\text { CLAY, dark brown, very fine sand to very fine } \\
\text { pebbles, } 2 \% \text { basalt gravel, } 2 \% \text { total sand, and } \\
96 \% \text { silt and clay, lithified by silt and clay } \\
\text { submature }\end{array}$ \\
\hline 197 & 202 & gravel & 16 & 100 & 47 & $\begin{array}{l}\text { CONGLOMERATE, dark brown, very fine sand to } \\
\text { cobbles, } 28 \% \text { other gravel, } 60 \% \text { basalt gravel, } \\
\text { and } 12 \% \text { sand, silt, and clay, lithified by } \\
\text { silt and clay, immature }\end{array}$ \\
\hline 202 & 209 & gravel & $17-18$ & 100 & 100 & $\begin{array}{l}\text { CONGLOMERATE, brownish black, very fine sand } \\
\text { to large cobbles, } 85 \% \text { basalt gravel and } 15 \% \\
\text { silt and clay, lithified by silt and clay, } \\
\text { immature, diatomite present throughout }\end{array}$ \\
\hline 209 & 222 & basalt & $18-20$ & 100 & 100 & $\begin{array}{l}\text { BASALT, black to gray, fractured, vesicular, } \\
\text { with yellow mineraloids in fractures and } \\
\text { clean vugs }\end{array}$ \\
\hline
\end{tabular}



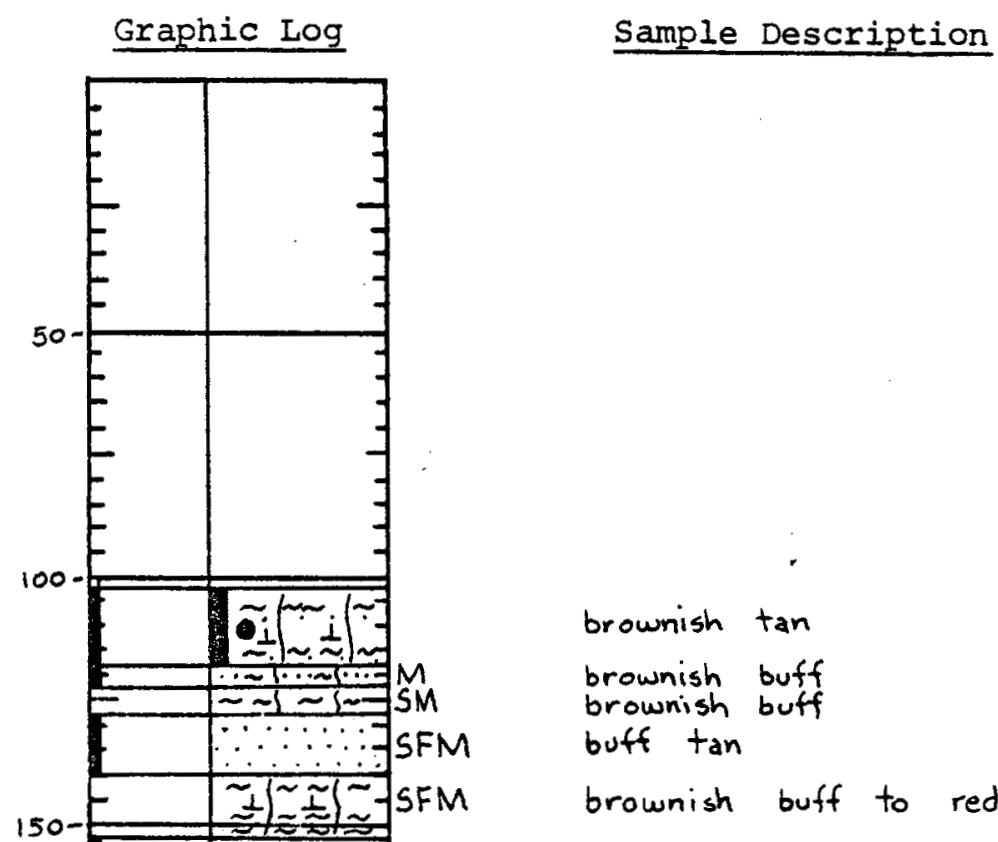

150
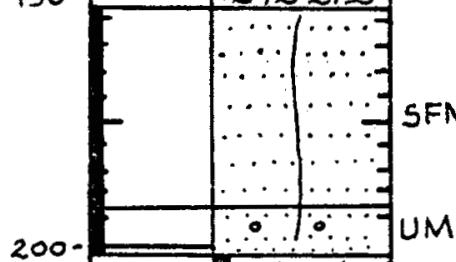

$=\sim \sim \sim \sim \sim 2$

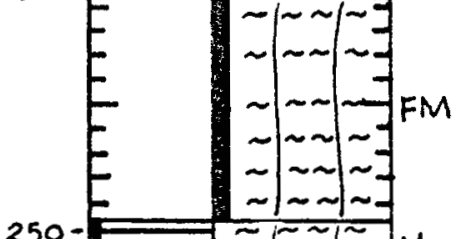

25
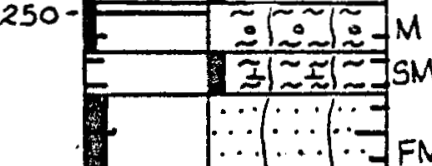

FM
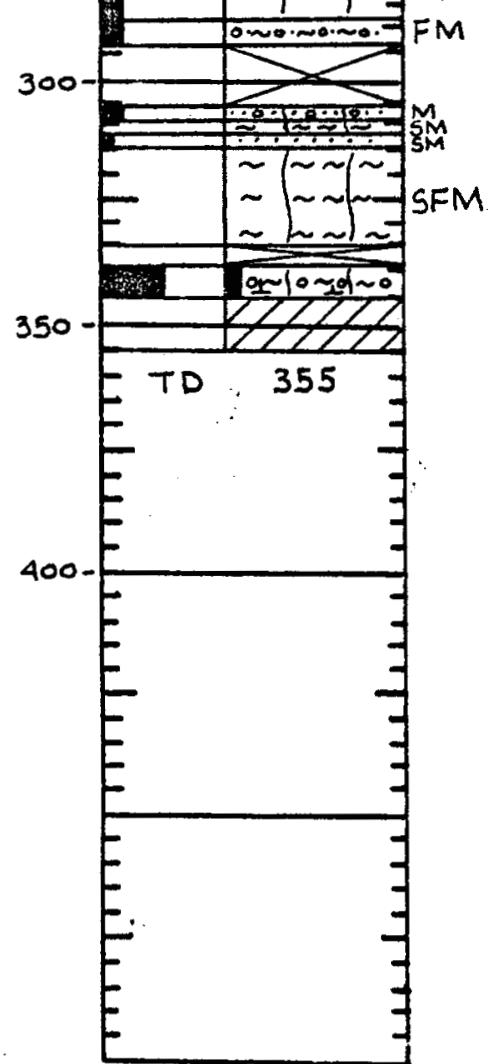

Plant Coordinates

$N \quad 053873$

$\frac{W \quad 017345}{\text { Altitude } 404}$

Other Data used in Interpretation

(1) Driller's Log

(2) Geologist's Log brownish $\tan$

brownish buff

brownish buff

buff $\tan$

brownish buff to reddish $\tan$

brownish buff

brownish buff

dark brown

dark brown

medium to dark brown

buff

brownish buff

buff brown

Greenish grey

light to dark brown

black 
Table 7 -- Descriptive log of well no. DH-9B (699-54-17C, N053873, w017345, 404.4 feet ms $\left.{ }^{1}\right)^{2}$.

1. casing elevation

2. personal communication with Roy Gephart, 11-20-75

$\frac{\text { Depth (ft) }}{\text { From To }}$

-

$103 \quad 118$

Classification

sandy silt

slightly silty

sand

$122.5 \quad 128$

silt

$4-5$

100

$6-8$

100

$128 \quad 140 \quad$ sand

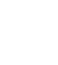

8-11

97

\section{Description}

MUDSTONE, brownish tan, very fine sand to fine pebbles, 4\% basalt gravel, 15\% other sand (angular), 2\% basalt sand, 79\% silt and clay, lithified with disseminated calcium carbonate and caliche, immature, micaceous, fractures present, caliche occurs as coatings in vugs and as sand and pebbles

SANDSTONE, brownish buff, very fine to fine sand, 76\% other sand (angular), 9\% basalt sand, and 15\% silt and clay, lithified by silt and clay, immature, micaceous, fractured, organic (?) stains present

MUDSTONE, brownish buff, very fine to fine sand, 4\% other sand (angular), 1\% basalt sand, and 95\% silt and clay, lithified by silt and clay, submature, micaceous, fractures present

SAND, buff tan, fine to medium sand sized, $89 \%$ other sand (angular), less than $10 \%$ basalt sand, and less than 1\% silt (no clay), unconsolidated, submature, frosted quartz, micaceous throughout

MUDSTONE (interbedded), brownish buff to reddish tan, very fine to medium sand, 4\% other sand (subangular), trace of basalt sand, and $96 \%$ silt and clay, lithified by calcium carbonate (in silt layers only), submature, frosted quartz, micaceous, laminations of silt-clay and sand interbeds 143-145, sands contain red sandstone intraclasts 
Depth (ft)

From

153.4193

Classification

sand

slightly

gravelly sand

$19-21$

67

Cores

runs orecovery ointact

11-18 $\quad 100$

100

193

202

gravelly sand

\section{Description}

SAND, brownish buff, very fine sand to fine pebbles, less than $1 \%$ basalt gravel, $87 \%$ other sand (subangular), 5\% basalt sand, 7\% silt and clay, compacted, submature, frosted quartz, fractured, micaceous, thin sand-silt and clay interbeds 153.4-158

SAND-CONGLOMERATE (interbedded), brownish buff, very fine sand to large cobbles, 7\% other gravel, $79 \%$ other sand (subrounded), $9 \%$ basalt sand, and 5\% clay (with little to no silt), compacted, immature, unfrosted quartz, micaceous, fractured, with interstitial limonite, hematite, and clay cementing interbedded gravels, clay in first sand occurs as angular interclasts, remainder of unit has disseminated clays

MUDSTONE, dark brown, very fine sand to fine pebbles, 2\% basalt gravel, $17 \%$ other sand (subrounded), 2\% basalt sand, and 79\% silt and clay, lithified by caliche, silt, and clay, fractured, immature, frosted quartz, micaceous, abundant caliche, root or twig casts 202-207; mud cracks and resulting clay intraclasts present 207-207.4; more caliche present in vugs and cracks 217-222, no caliche below 237 and no vugs from 242 to 247.9

MUDSTONE-CONGLOMERATE, dark brown, very fine sand to small cobbles, $6 \%$ other gravel, $8 \%$ basalt gravel, 13\% other sand (rounded), 1\% basalt sand, and $72 \%$ silt and clay, lithified by silt and clay, immature, micaceous, fractured, thin interbeds of pebbly silts and silty clays 
Table 7 -- Descriptive log of well no. DH-9B cont

\begin{tabular}{|c|c|c|c|c|c|c|}
\hline \multicolumn{2}{|c|}{ Depth (ft) } & \multirow[b]{2}{*}{ Classification } & \multicolumn{3}{|c|}{ Cores } & \multirow[b]{2}{*}{ Description } \\
\hline From & To & & runs & \&recovery & sintact & \\
\hline 258 & 267 & silt & $34-35$ & 100 & 89 & $\begin{array}{l}\text { MUDSTONE, medium to dark brown, very fine } \\
\text { to medium sand, } 28 \text { other sand (rounded), } \\
\text { trace of basalt sand, and } 98 \% \text { silt and } \\
\text { clay, lithified by caliche, silt and clay, } \\
\text { submature, fractured, micaceous, with } \\
\text { caliche along cracks and vugs }\end{array}$ \\
\hline 267 & 289 & sand & $35-40$ & 100 & 51 & $\begin{array}{l}\text { SANDSTONE, buff, very fine to medium sand } \\
\text { sized, 66\% other sand (subrounded), 15\% } \\
\text { basalt sand, and } 19 \% \text { silt and clay, uncon- } \\
\text { solidated to lithified as clay and silt } \\
\text { first occur as abundant (less than or equal } \\
\text { to } 25 \% \text { ) interclasts } 267-268 \text { and then are } \\
\text { present as disseminated, interstitial } \\
\text { material, immature, frosted quartz, frac- } \\
\text { tured, micaceous throughout }\end{array}$ \\
\hline 289 & 294 & $\begin{array}{l}\text { silty sandy } \\
\text { gravel }\end{array}$ & 41 & 60 & 23 & $\begin{array}{l}\text { CONGLOMERATE, brownish buff, very fine sand } \\
\text { to large cobbles, } 52 \% \text { other gravel, } 13 \% \\
\text { basalt gravel, } 16 \% \text { other sand (rounded), } 4 \% \\
\text { basalt sand, and } 15 \% \text { silt and clay, lith- } \\
\text { ified by interstitial iron oxides, silt } \\
\text { and clay, immature, frosted quartz, graded } \\
\text { bedding, micaceous, with abundant iron } \\
\text { oxide stains and iron concretions }\end{array}$ \\
\hline 294 & 306 & & $42-44$ & 0 & 0 & no sample \\
\hline 306 & 309 & $\begin{array}{l}\text { gravelly silty } \\
\text { sand }\end{array}$ & 45 & 100 & 56 & $\begin{array}{l}\text { SANDSTONE, buff brown, very } \\
\text { fine sand to very coarse pebbles, } 13 \% \text { other } \\
\text { gravel, } 7 \% \text { basalt gravel, } 40 \% \text { other sand } \\
\text { (rounded), 10\% basalt sand, and } 30 \% \text { silt, } \\
\text { lithified by silt, immature, micaceous } \\
\text { throughout }\end{array}$ \\
\hline
\end{tabular}


Table 7 -- Descriptive log of well no. DH-9B cont

Depth (ft)
occurring as a varved clay sequence that is lithified, submature, micaceous throughout

SANDSTONE, brownish buff, rounded, very fine to fine sand, $88 \%$ other sand, $10 \%$ basalt sand, and less than $2 \%$ silt and clay, lithified by iron oxides, silt, and clay, submature, iron concretions present 312312.5, micaceous throughout

312.5, micaceous throughout fine sand, $4 \%$ other sand (well rounded), trace of basalt sand, and $96 \%$ silt and clay, lithified by silt and clay, submature, frosted quartz, micaceous throughout, faint graded bedding 3.14-318

\begin{tabular}{|c|c|c|c|c|}
\hline 339 & & 53 & 0 & 0 \\
\hline 345.5 & silty gravel & $54-56$ & 50 & 46 \\
\hline
\end{tabular}

no sample

CONGLOMERATE, black, very fine sand to large cobbles, 3\% other gravel, 52\% basalt gravel, $5 \%$ other sand (angular), trace of basalt sand, $40 \%$ silt and clay, lithified by disseminated calcium carbonate, caliche, and silt and clay, immature, with caliche in fractures and vugs

BASALT, black, vesicular to massive, fractured, caliche and silt and clay are present along fractures and lack mineraloids 345.5350 , with little to no fracture fill and mineraloids present in vugs $350-355$ 


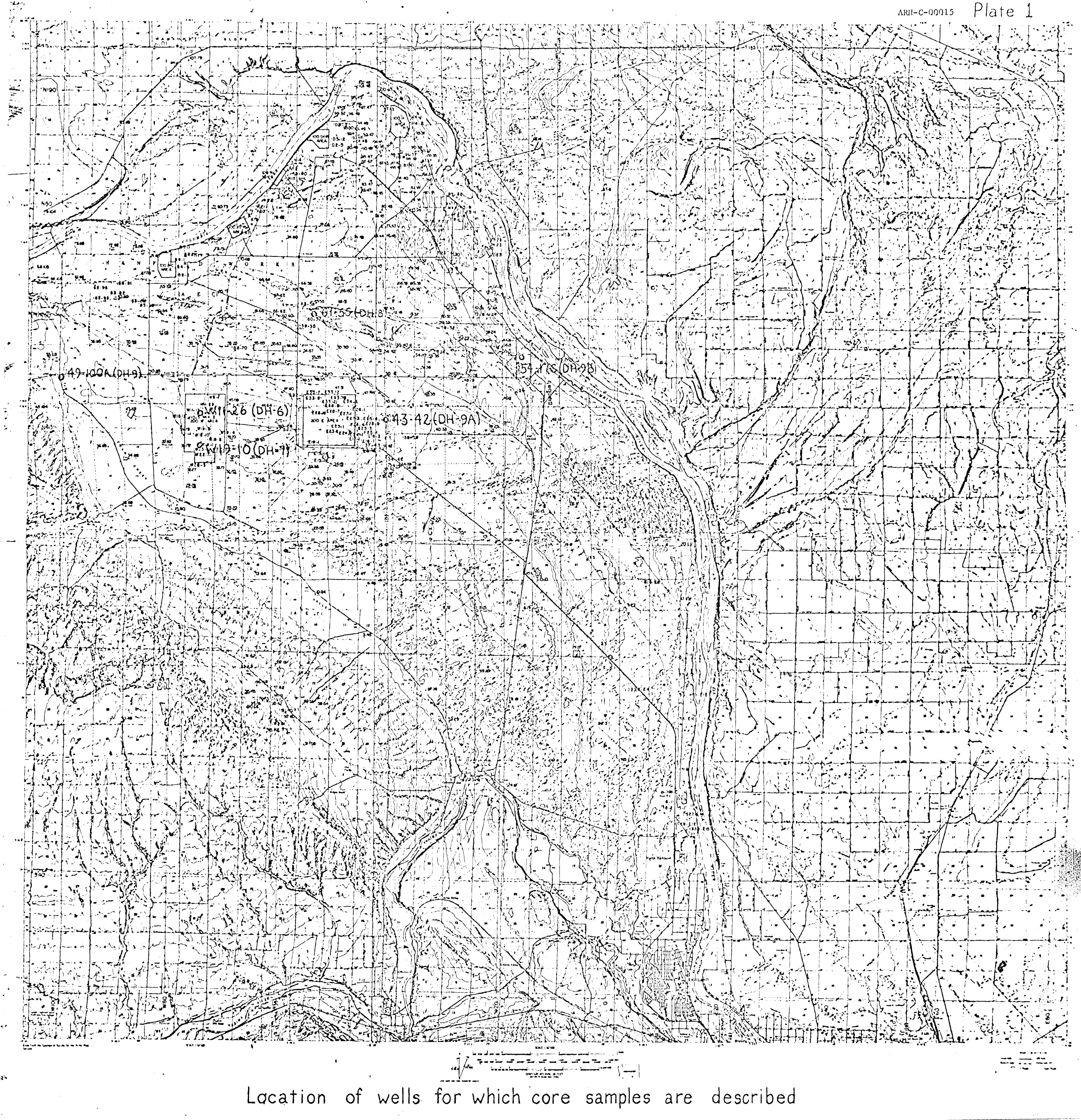

